
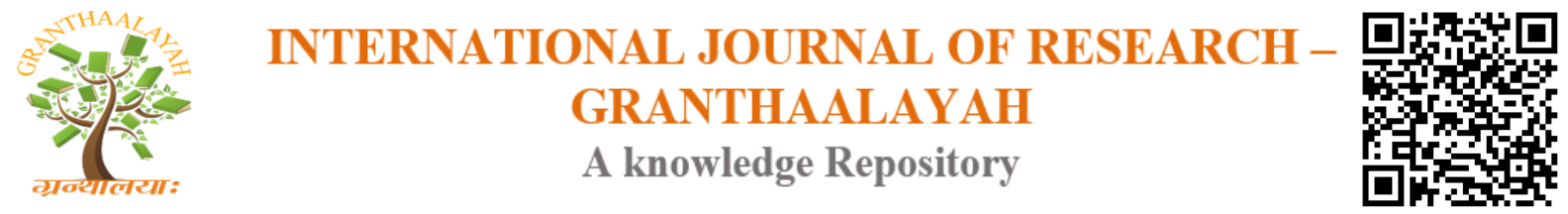

Science

\title{
EFFECT OF SOAK PIT ON THE CONSOLIDATION BEHAVIOR OF THREE ZONE SOIL IN KARNATAKA
}

\author{
Dr.K.V.Manoj Krishna ${ }^{* 1}$, B.T.Shivendra ${ }^{* 2}$ \\ ${ }^{1,2}$ Associate Professor, Department of Civil Engineering, Dayananda Sagar College of \\ Engineering, K S Layout, B-78, India
}

\begin{abstract}
The present research work discuss about the consolidation behavior of three zone soil which are collected neat soak pit regions from kanakapura, Hoskote and Dodaballapur, Karnataka, India at a depth of 0.5 meters from natural ground level and at a radial distance of 2.5 meters away from the pit area by using auger boring. In the above regions human excreta with sewage is directly discharged into these pits. From the pit contaminants will travel a maximum distance of 10 meters and also may travel vertically downwards and pollute the underground water and it also affects the engineering behavior of soil. So we are interested to know the consolidation characteristics of these regions soil. An attempt also made to have a consolidation comparative study of three above specified zone soil due to intrusion of contaminants. From the one dimensional fixed ring Consolidation test it is observed that Hoskote soil requires higher PreConsolidation pressure and hence its rate of permeability is less compared to other soils on the other hand Dodballapur soil requires lower Pre-Consolidation pressure for Consolidation of soil. This reflects the softening of soil due to contaminants intrusion near soak pit area.
\end{abstract}

Keywords: Compaction Energy; Pre-Consolidation Pressure; Permeability.

Cite This Article: Dr.K.V.Manoj Krishna, and B.T.Shivendra. (2017). "EFFECT OF SOAK PIT ON THE CONSOLIDATION BEHAVIOR OF THREE ZONE SOIL IN KARNATAKA." International Journal of Research - Granthaalayah, 5(11), 60-69. https:// doi.org/10.29121/granthaalayah.v5.i11.2017.2329.

\section{Introduction}

In India around $60 \%$ of the population they are using the open place for dumping human excreta in the form of dumping yards and soak pits in village or town respectively. The environmental scientists are against this method of waste disposal system. According to Banerjee(2011) and Shivendra-Ramaraju (2015) done research work on underground pollution travel from leachate pit of onsite sanitation facilities and impacts of onsite sanitation system on ground water in different geological settings of peri urban areas respectively. From there research work these researchers says contaminants can travel a maximum distance of 10 meters from the pit and also Shivendra and Ramaraju(2015), in their research work said that these contaminants will reaches 
up to ground water which depends on location of ground water table. As it leads to ground water contamination and also it reduces the angle of internal friction due to increase in the moisture content in the form of leachates. From the earlier literatures done few researches work on the horizontal flows of leachates. In their research they said that flow of leachates is effective up to 5 to 10 meters from the source of their collection. However, very few literatures are pointed about the vertical flow of these leachates and its ill effect on ground water contamination. In this paper an attempt is made to extract the basic information required for the evaluation of the vertical permeability of the soil from their collection and also we are planned to know the percentage reduction of strength and settlement behaviour of this soil before and after contamination flow through them. From the pit contaminants will travel a maximum distance of $10 \mathrm{mtrs}$ and also may travel vertically downwards and pollute the underground water table. Characteristics of three soils which is collected from Hoskote, Kanakpura and Doddaballapur region by using open pit excavation method from a depth of 0.5 meters from natural ground level. From the above conclusion there is a change in engineering behaviour of soil from the laterine pits 5 to 10 meters far where the construction work is to be carried out. So we are planning to carry out an experiment to determine the changes in the behaviour of soil.

Wei-Cheng Lo et.al (2016) says that, the one-dimensional consolidation model of poro elasticity of Ming-Xin Zhengc et.al (2014), for an unsaturated soil under constant loading is generalized to include an arbitrary time-dependent loading. A closed-form solution for the pore water and air pressures along with the total settlement is derived by employing a Fourier series representation in the spatial domain and a Laplace transformation in the time domain. This solution is illustrated for the important example of a fully-permeable soil cylinder with an undrained initial condition acted upon by a periodic stress. Our results indicate that, in terms of a dimensionless time scale, the transient solution decays to zero most slowly in water- saturated soil, whereas for an unsaturated soil, the time for the transient solution to die out is inversely proportional to the initial water saturation. The generalization presented here shows that the diffusion time scale for pore water in an unsaturated soil is orders of magnitude greater than that in a water-saturated soil, mainly because of the much smaller hydraulic conductivity of the former.

\section{Materials and Methods}

The present research work is done by collecting soils from Kanakapura, Hoskote and Dodballapura, Karnataka, India from a depth of 0.5 meter from natural ground work and within 2.5 meters radius from the soak pit. Except sieve analysis all the tests were conducted by taking soil passing through $425 \mu$ BIS sieve. Table 1.0 indicates basic properties of three zone soils.

Table 1: Basic properties of three zone soils

\begin{tabular}{|l|l|l|l|}
\hline Properties & Dodballapur Soil & Kanakpura Soil Hoskote Soil \\
\hline Colour & Red & Black & Black \\
\hline Specific gravity & 2.55 & 2.54 & 2.54 \\
\hline Soil sample collected Season & Dry & Dry & Dry \\
\hline Moisture content & 11.65 & 6.56 & 7.14 \\
\hline Bulk density kN/m ${ }^{3}$. & 14.9 & 14.2 & 15.2 \\
\hline Void ratio & 0.61 & 0.65 & 0.74 \\
\hline Degree of saturation $(\%)$ & 45.83 & 23.27 & 25.54 \\
\hline
\end{tabular}




\begin{tabular}{|l|l|l|l|}
\hline Porosity (\%) & 37.89 & 39.54 & 34.21 \\
\hline Permeability ( m/Day) & $8.6 \times 10-3$ & $1.21 \times 10-2$ & $5 \times 10-3$ \\
\hline OMC $(\%)$ & 17.5 & 16.0 & 16.0 \\
\hline MDD $\left(\mathrm{kN} / \mathrm{M}^{3}\right)$ & 18.2 & 18.7 & 18.4 \\
\hline
\end{tabular}

\subsection{Compaction Test Using Specially Designed Mini Compaction Assembly}

Compaction of the soil is carried out by using mini compaction test apparatus designed by IISc Prof.A.Sridharan and P.V.Shivapulliah (2005) and remodified by Dayananda Sagar College of Engineering Facutly K.V.Manoj Krishna (2009). Ramesh et.al (2010), says that the compaction results obtained from this mini compaction test is $98 \%$ same as light compaction equipment proposed by IS2720 guidelines.

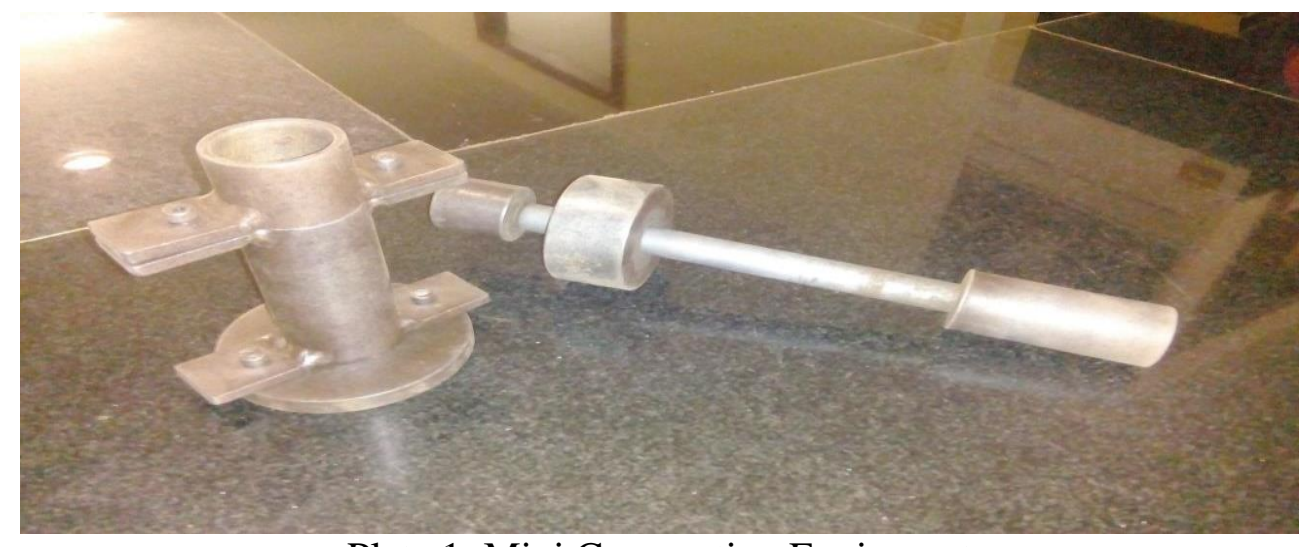

Plate 1: Mini Compaction Equipment

(Courtesy by P G student report guided by Dr. K V Manoj Krishna)

Consolidation test is conducted as per IS: 2720 Guidelines
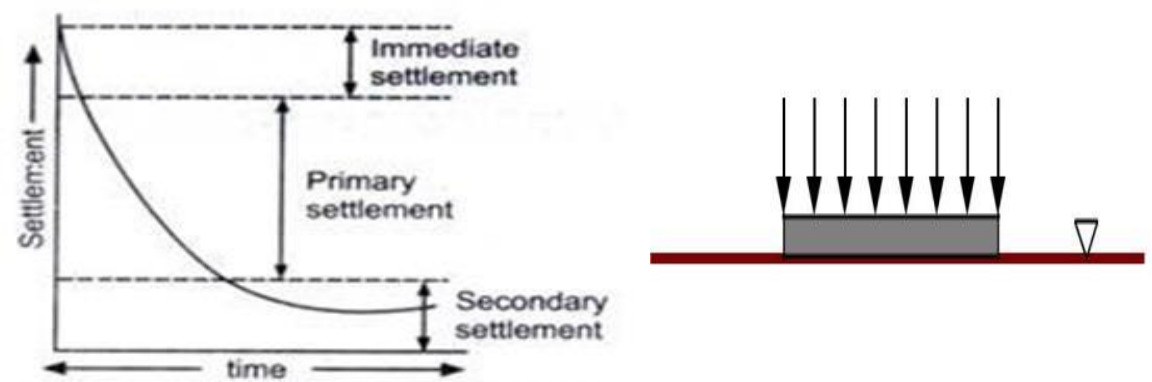

Settlement
Primary
Saturated clay

Photo 2: Typical consolidation plot and footing load transferred to saturated clay (Courtesy by Dr. S V Dinesh, Professor)

\subsection{Normally Consolidated Soils}

It is a soil deposit that has never subjected to a vertical effective stress greater than the present vertical stress. The stress state $\sigma 2^{\prime}$ represent normally consolidated soil. 

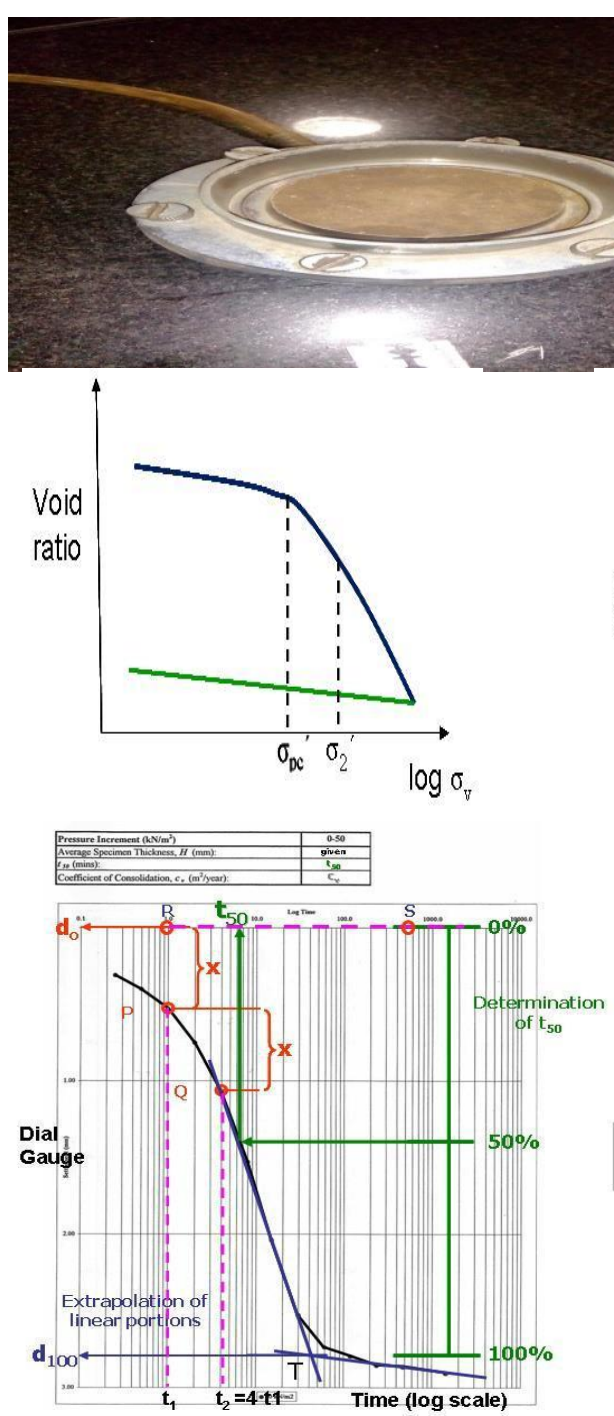

Plate 3: Consolidation samples, typical plot of Void ratio vs effective stress and Cv calculation by two methods

\section{Results and Discussions}

Compaction test is conducting for above specified soil by using mini compaction test apperaturs and consolidation test is conducted by using single gang consolidation cell as per IS:2720 guidelines. The results were discussed as below.

\subsection{Compaction Behavior of Three Soils}

Table 1.0 and Fig.1.0 it is observed that Kanakapura soil having higher maximum dry density than Hoskote soil and Dodballapura soil. Also Kanakaura soil is moving towards dry of optima on compared with Dodballapur soil. This indicates that with same compacting effect, higher density is achieved for Kanakapura soil on compared with other two places soil. 


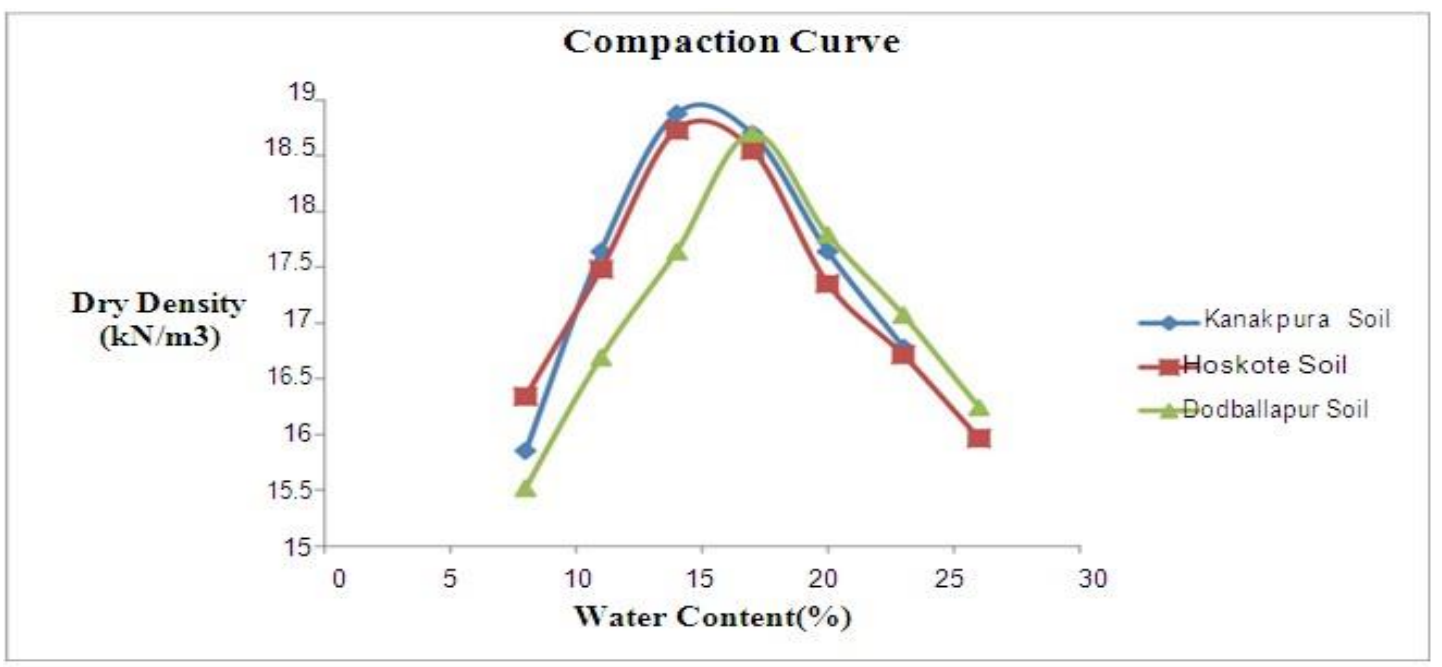

Figure 1: Density Vs Moisture content of three soils

\subsection{Consolidation Behavior of Three Soils}

The remolded consolidation soil samples were prepared to their maximum dry density and corresponding optimum moisture content. The results of 24 hours per loading consolidation test were reflected the the following Table 2.0 to 4.0 and also the behavior of soil with varying pressure were reflected in the Fig.2.0 to Fig. 7.0.

Table 2: Variation of void ratio with increase in pressure av /1+e for Kanakpura Soil

\begin{tabular}{|c|c|c|c|c|c|c|c|}
\hline $\begin{array}{l}6 \\
\mathrm{Kg} / \mathrm{cm}^{2}\end{array}$ & $\Delta \sigma \mathrm{kg} / \mathrm{cm}^{2}$ & ${ }^{2} \mathrm{H} \mathrm{cm}$ & $\Delta \mathrm{H}$ & $\mathrm{e}$ & e & $\begin{array}{l}\mathrm{av}= \\
(\Delta \mathrm{e} / \Delta \sigma) \\
\mathrm{cm}^{2} / \mathrm{Kg}\end{array}$ & $\begin{array}{l}\mathrm{mv}=\mathrm{av} / 1+\mathrm{e} \\
\left(\mathrm{cm}^{2} / \mathrm{kg}\right)\end{array}$ \\
\hline \multirow[t]{2}{*}{0} & & 1.9 & & & 0.19 & & \\
\hline & 0.5 & 1.887 & -0.013 & -0.0082 & & 0.01632 & 0.01368 \\
\hline \multirow[t]{2}{*}{0.5} & & & & & 0.18 & & \\
\hline & 0.5 & 1.881 & -0.006 & -0.0038 & & 0.00753 & 0.00636 \\
\hline \multirow[t]{2}{*}{1} & & & & & 0.18 & & \\
\hline & 1 & 1.869 & -0.012 & -0.0075 & & 0.00753 & 0.00638 \\
\hline \multirow[t]{2}{*}{2} & & & & & 0.17 & & \\
\hline & 2 & 1.85 & -0.019 & -0.0119 & & 0.00596 & 0.00508 \\
\hline \multirow[t]{2}{*}{4} & & & & & 0.16 & & \\
\hline & 4 & 1.82 & -0.03 & -0.0188 & & 0.00471 & 0.00405 \\
\hline \multirow[t]{2}{*}{8} & & & & & 0.14 & & \\
\hline & -4 & 1.823 & 0.003 & 0.0019 & & 0.00047 & 0.00041 \\
\hline \multirow[t]{2}{*}{4} & & & & & 0.14 & & \\
\hline & -2 & 1.825 & 0.002 & 0.0013 & & 0.00063 & 0.00055 \\
\hline 2 & & & & & 0.15 & & \\
\hline
\end{tabular}




\begin{tabular}{|l|l|l|l|l|l|l|l|}
\hline & -1 & 1.83 & 0.005 & 0.0031 & & 0.00314 & 0.00274 \\
\hline 1 & & & & & 0.15 & & \\
\hline & -0.5 & 1.8320 .002 & 0.0013 & & 0.00251 & 0.00219 \\
\hline 0.5 & & & & & 0.15 & & \\
\hline
\end{tabular}

Table3: Variation of void ratio with increase in pressure av/1+e for Dodballapur Soil.

\begin{tabular}{|l|l|l|l|l|l|l|l|}
\hline $\begin{array}{l}\sigma \\
\mathrm{Kg} / \mathrm{c} \\
\mathrm{m}^{2}\end{array}$ & $\begin{array}{ll}\mathrm{kg} / \mathrm{c} \\
\mathrm{m}^{2}\end{array}$ & $\mathrm{H} \mathrm{cm}$ & $\Delta \mathrm{H}$ & $\Delta \mathrm{e}$ & $\mathrm{e}$ & $\begin{array}{l}\mathrm{av}= \\
(\Delta \mathrm{e} / \Delta \sigma) \\
\mathrm{cm}^{2} / \mathrm{Kg}\end{array}$ & $\begin{array}{l}\mathrm{mv}=\mathrm{av} / 1+\mathrm{e} \\
\left(\mathrm{cm}^{2} / \mathrm{kg}\right)\end{array}$ \\
\hline & & & & & & & \\
\hline 0 & & 1.9 & & & 0.19 & & \\
\hline & 0.5 & 1.832 & -0.068 & -0.0535 & 0.49 & 0.10690 & 0.07165 \\
\hline 0.5 & & & & & & & \\
\hline & 0.5 & 1.812 & -0.02 & -0.0157 & 0.44 & 0.03144 & 0.02186 \\
\hline 1 & & & & & & & \\
\hline & 1 & 1.769 & -0.043 & -0.0338 & 0.42 & 0.03380 & 0.02376 \\
\hline 2 & & & & & & & \\
\hline & 2 & 1.726 & -0.043 & -0.0338 & 0.39 & 0.01690 & 0.01217 \\
\hline 4 & & & & & & & \\
\hline & 4 & 1.682 & -0.044 & -0.0346 & 0.36 & 0.00865 & 0.00638 \\
\hline 8 & & & & & & & \\
\hline & -4 & 1.687 & 0.005 & 0.0039 & 0.32 & 0.00098 & 0.00074 \\
\hline 4 & & & & & & & \\
\hline & 2 & 1.688 & 0.001 & 0.0008 & 0.32 & 0.00039 & 0.00030 \\
\hline 2 & & & & & & & \\
\hline & -1 & 1.69 & 0.002 & 0.0016 & 0.33 & 0.00157 & 0.00119 \\
\hline 1 & & & & & & & \\
\hline & 0.5 & 1.692 & 0.002 & 0.0016 & 0.33 & 0.00314 & 0.00237 \\
\hline 0.5 & & & & & 0.33 & & \\
\hline
\end{tabular}

Table4: Variation of void ratio with increase in pressure av/1+e for Hoskote Soil.

\begin{tabular}{|c|c|c|c|c|c|c|c|}
\hline $\begin{array}{l}6 \\
\mathrm{Kg} / \mathrm{cm}^{2}\end{array}$ & $\begin{array}{l}\Delta \sigma \\
\mathrm{kg} / \mathrm{cm}^{2}\end{array}$ & $\mathrm{H} \mathrm{cm}$ & $\Delta \mathrm{H}$ & $\Delta \mathrm{e}$ & $\mathrm{e}$ & $\begin{array}{l}\mathrm{av}= \\
(\Delta \mathrm{e} / \Delta \sigma) \\
\left(\mathrm{cm}^{2} / \mathrm{Kg}\right)\end{array}$ & $\begin{array}{l}\mathrm{mv}=\mathrm{av} / 1+\mathrm{e} \\
\left(\mathrm{cm}^{2} / \mathrm{kg}\right)\end{array}$ \\
\hline \multirow[t]{2}{*}{0} & & 1.9 & & & 0.51 & & \\
\hline & 0.5 & 1.861 & -0.039 & -0.0309 & & 0.06184 & 0.04105 \\
\hline \multirow[t]{2}{*}{0.5} & & & & & 0.48 & & \\
\hline & 0.5 & 1.851 & -0.01 & -0.0079 & & 0.01586 & 0.01075 \\
\hline \multirow[t]{2}{*}{1} & & & & & 0.47 & & \\
\hline & 1 & 1.831 & -0.02 & -0.0159 & & 0.01586 & 0.01080 \\
\hline \multirow[t]{2}{*}{2} & & & & & 0.45 & & \\
\hline & 2 & 1.8 & -0.031 & -0.0246 & & 0.01229 & 0.00847 \\
\hline
\end{tabular}


DOI: 10.5281/zenodo.1067672

\begin{tabular}{|l|l|l|l|l|l|l|l|}
\hline 4 & & & & \multicolumn{3}{|c|}{0.43} & \\
\hline & 4 & 1.751 & -0.049 & -0.0388 & & 0.00971 & 0.00681 \\
\hline 8 & & & & & 0.39 & & \\
\hline & -4 & 1.758 & 0.007 & 0.0055 & & 0.00139 & 0.00100 \\
\hline 4 & & & & & 0.39 & & \\
\hline & -2 & 1.768 & 0.01 & 0.0079 & & 0.00396 & 0.00284 \\
\hline 2 & & & & & 0.40 & & \\
\hline & -1 & 1.776 & 0.008 & 0.0063 & & 0.00634 & 0.00452 \\
\hline 1 & & & & & 0.41 & & \\
\hline & -0.5 & 1.781 & 0.005 & 0.0040 & & 0.00793 & 0.00563 \\
\hline 0.5 & & & & & 0.41 & & \\
\hline
\end{tabular}

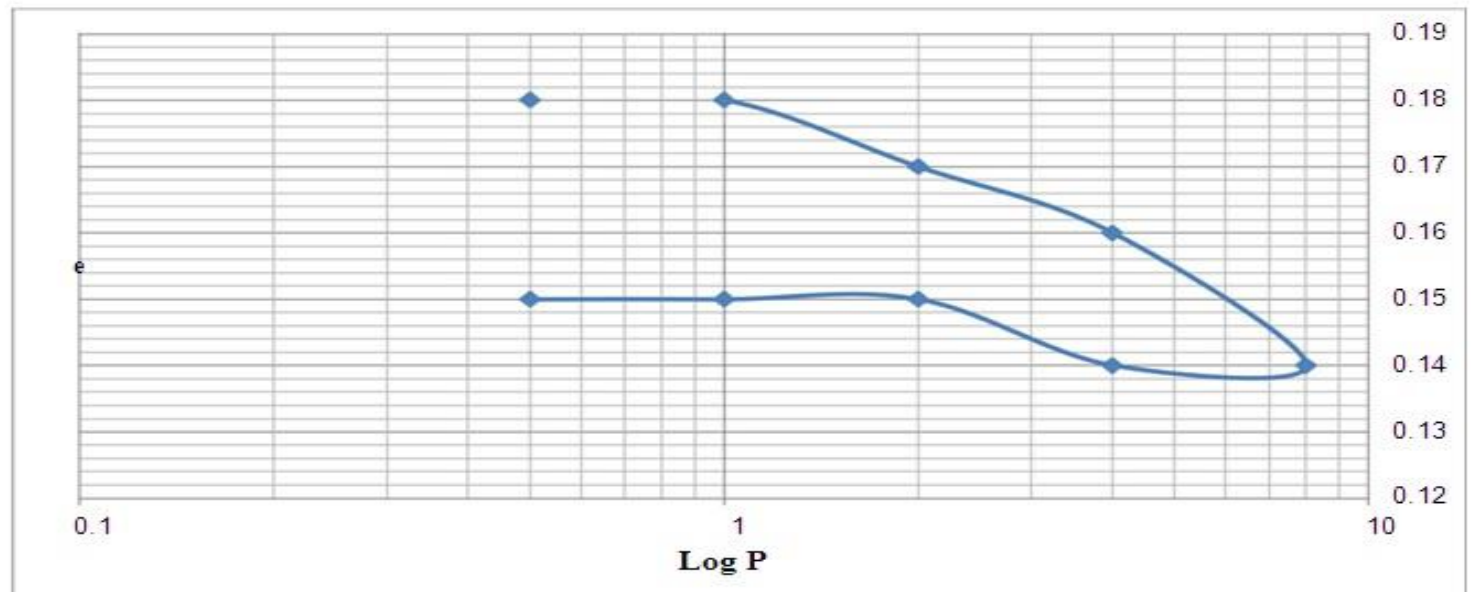

Figure 2: e-logp curve for Kanakpura Soil.

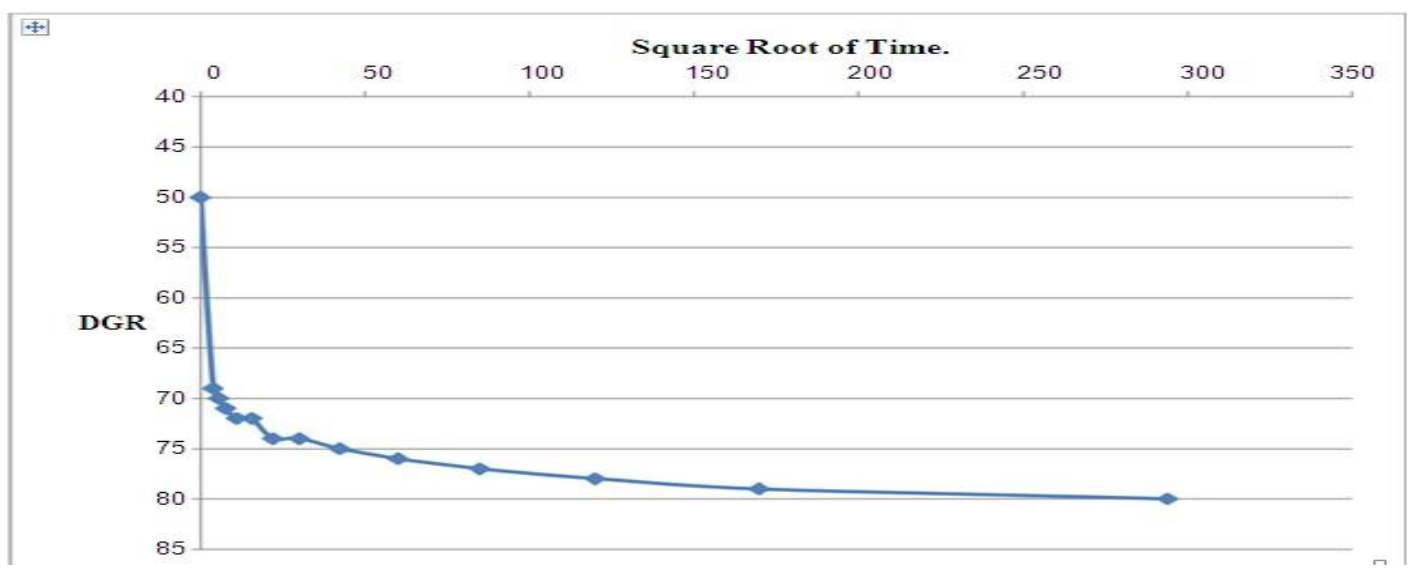

Figure 3: Square root of time fitting method of obtaining t 90 for $U=90 \%$ for Kanakpura soil 


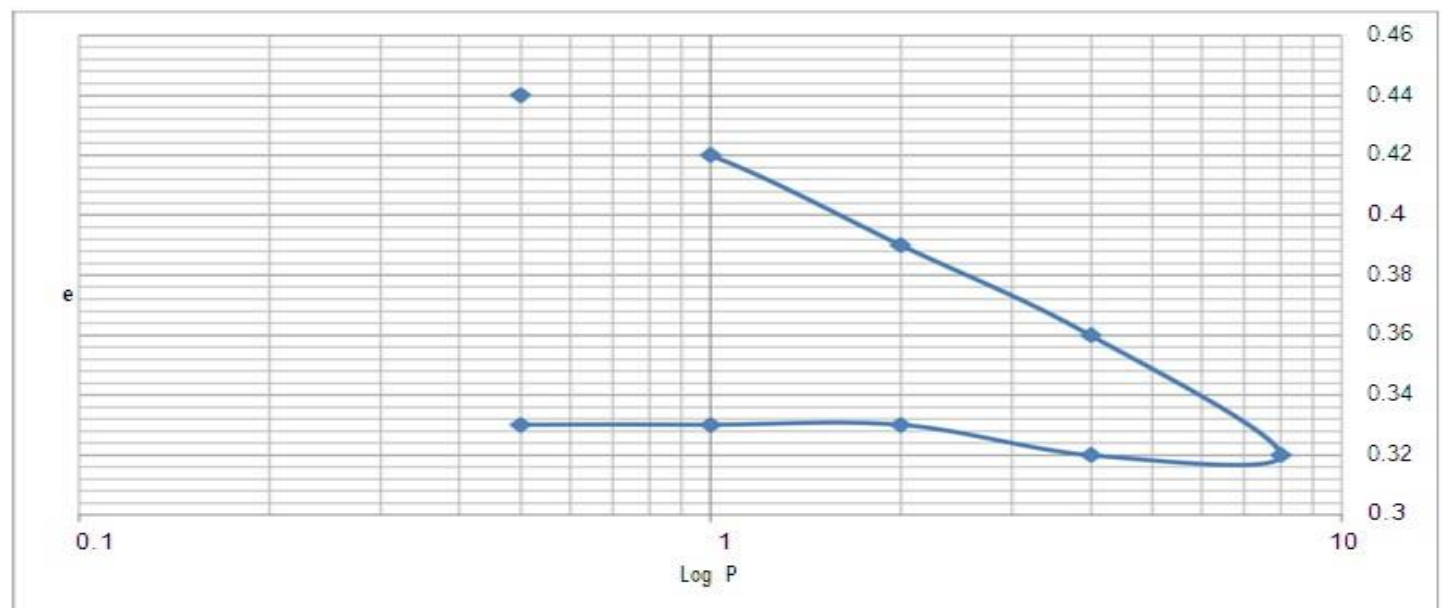

Figure 4: e-logp curve for Dodballapur Soil

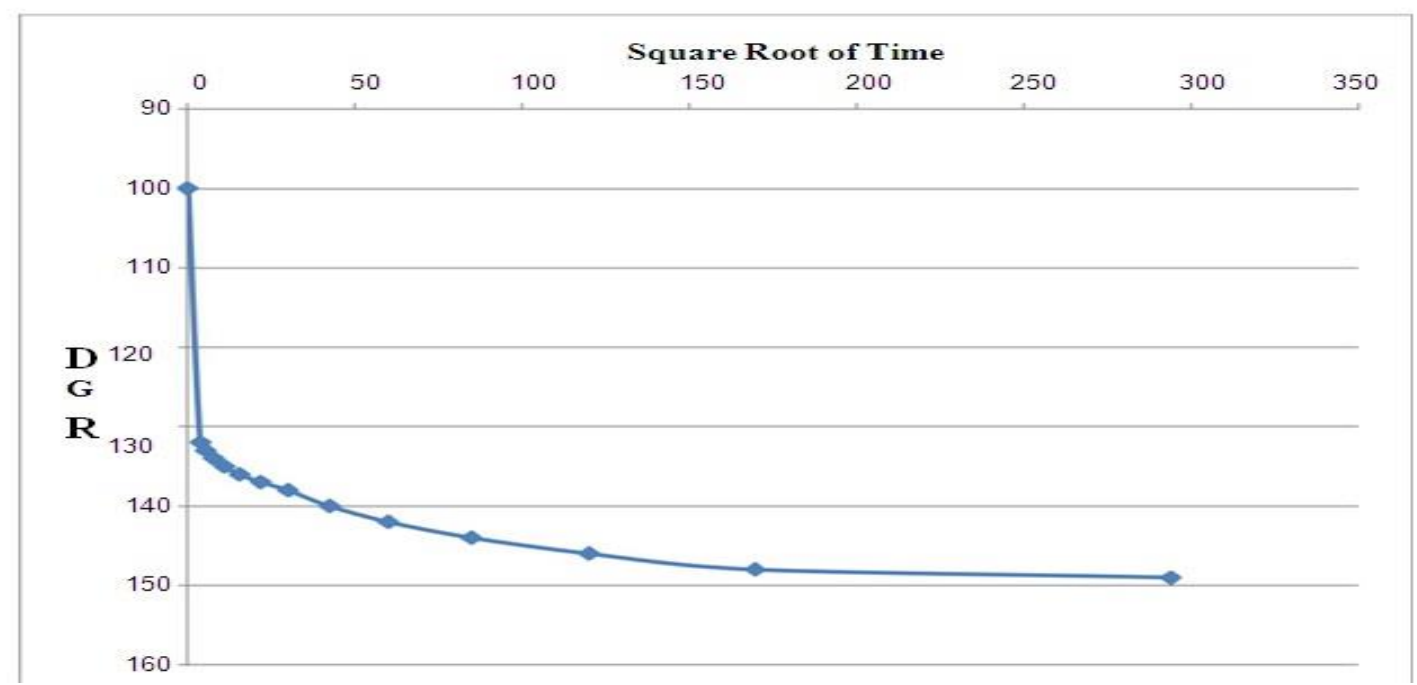

Figure 5: Square root of time fitting method of obtaining t90 for $U=90 \%$ for Dodaballapur soil

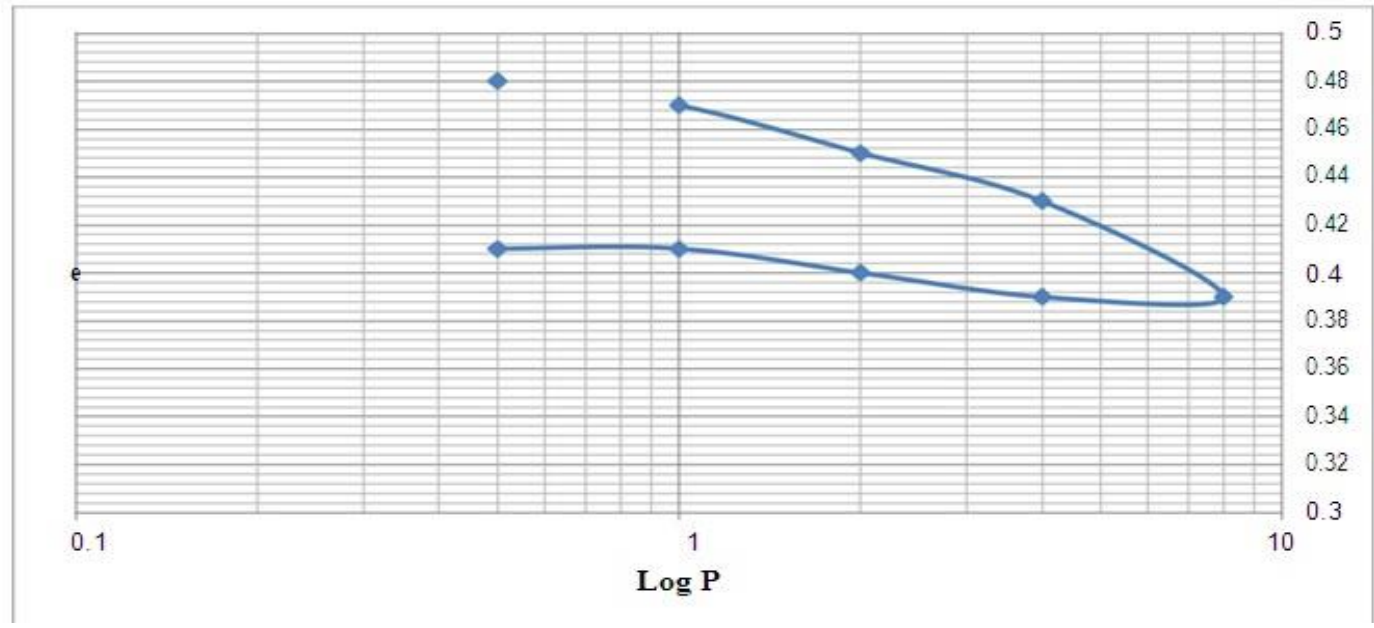

Figure 6: e-logp curve for Hosokota Soil 


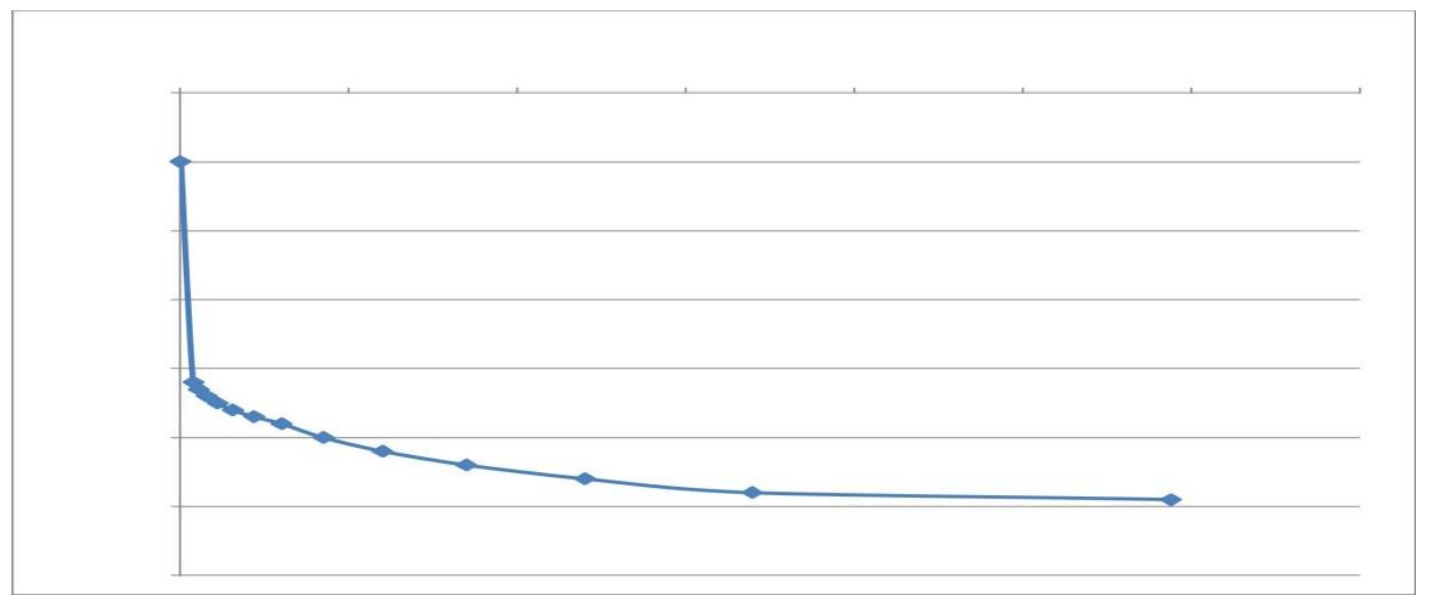

Figure 7: Square root of time fitting method of obtaining $\mathrm{t} 90$ for $\mathrm{U}=90 \%$ for Hosokota soil

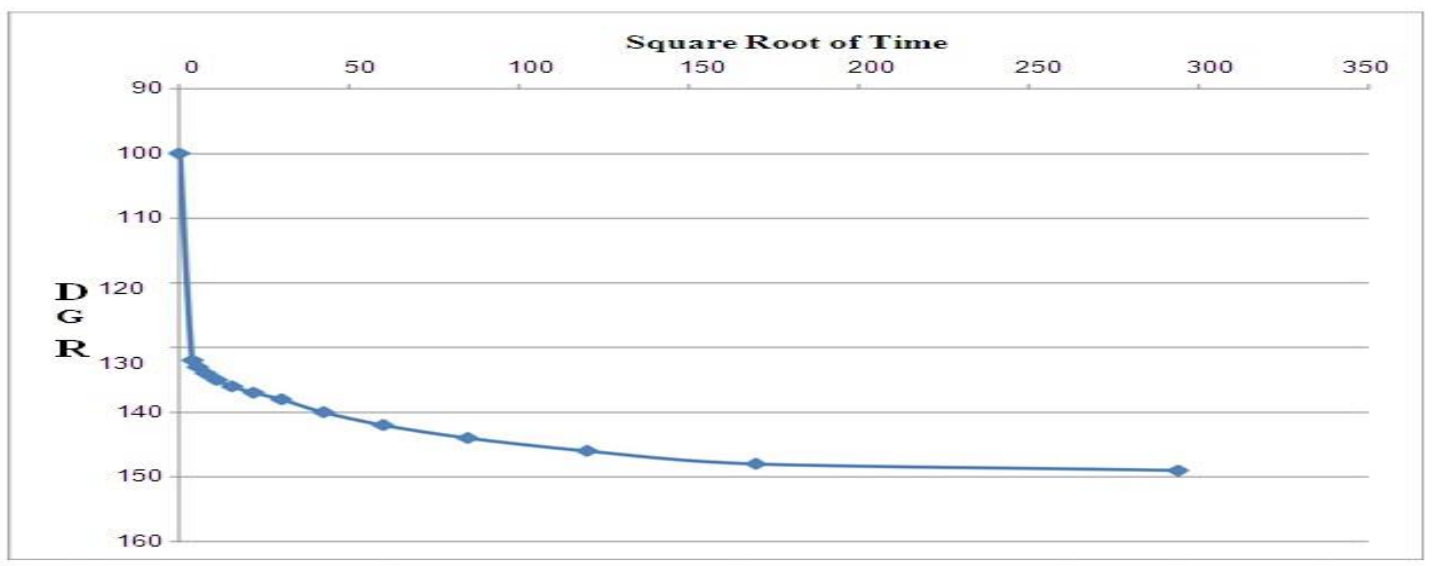

Fig 5.10 Square root of time fitting method of obtaining t90 for $U=90 \%$ for Hoskote Soil.

Table 5: Abstract for Pre Consolidation, Co efficient of Consolidation and Co efficient of Permeability for 3 soil samples after Consolidation.

\begin{tabular}{|l|l|l|l|l|l|l|}
\hline Location & $\begin{array}{l}\text { Existing } \\
\text { pressure } \\
0.5 \mathrm{~m} \\
\mathrm{kN} / \mathrm{m} 2)\end{array}$ & $\begin{array}{l}\text { 6p } \\
(\mathrm{kN} / \mathrm{m} 2)\end{array}$ & $\begin{array}{l}\mathrm{Kv} \\
(\mathrm{cm} 2 / \mathrm{sec})\end{array}$ & $\begin{array}{l}\mathrm{K} \\
(\mathrm{cm} / \mathrm{sec})\end{array}$ & $\begin{array}{l}\text { Field Density } \\
\text { Dry }(\mathrm{kN} / \mathrm{m} 3)\end{array}$ & $\begin{array}{l}\mathrm{MDD} \\
(\mathrm{kN} / \mathrm{m} 3)\end{array}$ \\
\hline Dodballapur Soil & 7.95 & 90 & $1.66 \times 10-3$. & $9.96 \times 10-6$ & 14.9 & 18.2 \\
\hline Kanakpura Soil & 7.14 & 190 & $3.5 \times 10-3$ & $1.401 \times 10-5$ & 14.26 & 18.7 \\
\hline Hoskote Soil & 7.9 & 200 & $9.65 \times 10-4$. & $5.79 \times 10-6$ & 15.2 & 18.4 \\
\hline
\end{tabular}

From Table 5.0 it is observed that all the three soil sample locations having existing vertical stress is less than the preconsolidation pressure, which was determined in laboratory. Hence all the three zone soils are normally consolidated soil deposit. From field density test it is observed that Hoskote soil is having higher average field density than kanakapura soil. From laboratory light compaction test it is observed that kanakapura soil is having higher maximum dry density than hoskote soil. This reflects that under existing field conduction kanakapura soil is more permeable than hoskote soil as well as, but after proper compaction permeability of kanakapur 
soil reduces. Also after compaction pre-consolidation pressure carrying capacity of dodaballapur soil is lower than other two zone soils.

\section{Conclusions and Recommendations}

Based on the laboratory investigation and analysis indicates following conclusions. They are as follows, namely

Kanakpura soil has higher laboratory density compared to Hoskote and Dodballapur soil.However, Hoskote soil having higher field density than other two zone soil. This indicates that Dodaballapur soil is lower resistance to consolidation.

From Pre Consolidation pressure it is observed that Dodballapur soil is having lower than to Kanakpura and Hoskote Soil.

It is necessary to check exact Permeability behaviour of soil by conducting field permeability test in the above three locations there are Kanakpura, Hoskote and Dodballapur regions.

Stabilization of soil by using chemicals is necessary at Dodballapur soil to improve the stabilization behavior.

\section{Acknowledgements}

We extend our sincere acknowledgement to students Aradhya T.G,Darshan A.M Kiran K as well as Mr.Sundar Raj \& Venkataram for their support in carrying our experimental works in DSCE Geotechnical Laboratory, b-78,Karnataka, India.

\section{References}

[1] Banerjee .G. (2011): Underground pollution travel from leach pits of on-site sanitation facilities: a case study. Clean Technol Envir 13, 1 2011, 489-497.

[2] Shivendra.B.T. Ramaraju.H.K: Impact of onsite sanitation system on groundwater in different geological settings peri urban areas is published in Science Direct Aquatic Procedia Elsevier Publication. Aquatic Procedia 4, $2015,1162-1172$

[3] Ming-Xin Zhengc et.al General solutions for consolidation of multilayered soil with a vertical drain system, Geotextiles and Geomembranes, 42, 3, 2014, 267-276.

[4] Wei-Cheng Lo et.al One-dimensional consolidation in unsaturated soils under cyclic loading, Advances in Water Resources, Volume 91, 2016, 122-137.

[5] IS 2720 (Part 15)-1986 Methods of tests for soil: Determination of Consolidation Properties.

[6] Ramesh H N, Manoj Krishna K.V and Mamatha H.V (2010) Compaction and strength behavior of lime-coir fiber treated black cotton soil, Geotechnics and Engineering; an international Journal published in USA-Korea, 2, 1, 2010, 19-28.

[7] Sridharan .A and Sivapulliah P.V (2005) Mini compaction test o determination of compaction characteristics of dine grained soil Geotechnical testing journal, 28,2005,240-246.

*Corresponding author.

E-mail address: gauravkumar.shaha@ gmail.com 